UDC 621.74 .045

V. Mazorchuk, Cand. Sc. (Tech.), Assoc. Prof., orcid.org/0000-0002-8512-0727,

I. Naumova, Cand. Sc. (Phys.-Math.), Assoc. Prof., orcid.org/0000-0002-4704-2756,

S. Repyakh, Dr. Sc. (Tech.), Assoc. Prof., orcid.org/0000-0003-0203-4135,

S. Sharkova, Cand. Sc. (Psychol.), orcid.org/0000-0003-0413-6960
DOI: $10.29202 /$ nvngu/2018-3/9

National Metallurgical Academy of Ukraine, Dnipro, Ukraine, e-mail: MazorchukVF@gmail.com; irnaumova.nmetau@ gmail.com; 123rs@ua.fm

\title{
THE STRESSES IN THE HOLLOW CYLINDRICAL COMBINED CASTINGS
}

Purpose. Development of the mathematical model for making theoretical analysis regarding the effect of design factors and physical properties of materials of the combined hollow cylindrical casting on a maximum pressure limit of a working body (gas, liquid) in it.

Methodology. Methods of comparative analysis, mathematic simulation and forecasting were used.

Findings. The mathematical model for theoretical analysis regarding the development of design factors of the combined hollow cylindrical casting on a maximum pressure limit of a working body in it has been presented.

Originality. Based on the results of theoretical research, ways of producing combined castings used under the increased internal pressure of working environment are shown. Furthermore, the suggested mathematical model facilitates the assessment of the effect of the properties of applied materials and dimensional factors of the casting on its boundary operation conditions.

Practical value. Use of the suggested model allows making calculations of the properties of cylindrical elements of hollow combined casting considering their geometric dimensions. The results of the research can be used for designing combined casting products such as isolation valve.

Keywords: combined casting, ceramic insert, radial and tangential stresses

Introduction. Nowadays there is a heavy demand for moulded pieces in flanged valves production. Typical flanged valves represent technical devices with the forced changing square of the inner flow section where the working environment is filled with gas, fluid, and other similar substances. Such valves control (seal or distribute) the flows of fluid, gas, gas-liquid, powder substance and abrasive materials. For these purposes flanged valves are installed in the locations easily accessible for operator or easily controlled by the actuator of the automated management system [1, 2].

Flanged valves are a critical element of a pipeline. It is proved by the fact that flanged valves made of alloyed steel or nonferrous alloys with the inner diameter of above $20 \mathrm{~mm}$ are certificated. The certificate of the required standard contains the following information: chemical composition of metal used for producing flanged valves, its mechanical properties, heat treatment modes, and the results of quality tests conducted by one or several methods of nondestructive testing. The number of industries where flanged valves are employed is constantly growing, which explains the need to produce larger quantity and wider range of products as well as advance design and operational properties (chemical resistance and vibratory stability, heat resistance and thermal stability, reliability and durability) of materials used for flanged valves production.

Analysis of the recent research and publications. Flanged valves work under the following conditions [3, 4]:

(C) Mazorchuk V., Naumova I., Repyakh S., Sharkova S., 2018
- low pressure of cold and hot (river, fresh and salt) water, gas, water vapor, and others;

- vacuum, high pressure, high and/or low temperature;

- transportation of corrosive, toxic, radioactive, viscous, abrasive, and granular substances;

- vibratory, dynamic and static loads, and others.

The mentioned above conditions predetermine the requirements for materials used for manufacturing core elements of flanged valves, first of all the parts which contact the working environment.

As a rule, core elements of flanged valves are made of metals, sometimes of plastic material (plastic), ceramics or glass.

Flanged valves made of glass and ceramics have high chemical resistance to corrosive substances, at the same time they are fragile and possess low strength. That is why such flanged valves are not employed in the working environment with significant impact loads and high pressure as well as in pipelines with large nominal diameter.

Plastic materials (polystyrene, polyvinyl chloride, polypropylene, polyethylene, and others) are abundant and cheap, have low strength, withstand a limited temperature range, and are prone to aging and abrasion. That is why flanged valves made of listed above materials are employed in pipelines with low nominal diameter and low pressure that operate at ambient temperatures [5-7].

Nowadays, such nonferrous metals as brass and bronze are widely used for manufacturing pipelines with low nominal diameter for transporting natural gas, water vapor, fresh and salt water, and other chemically neutral and low-active substances. 
Flanged valves made of aluminum alloys are cheaper and lighter than that made of copper alloys (brass and bronze), but at the same time have lower strength, durability and reliability.

Flanged valves made of titanium and titanium alloys are much stronger, harder, more reliable and durable, and have extremely higher chemical inertness than aluminum alloys. Such flanged valves are also much more expensive.

For increasing operating temperature and pressure range stop valves are sometimes made of other nonferrous metals, for example nickel and tantalum alloys, which pushes up their price sharply.

Flanged valves for industrial use are mainly made of cast iron or steel. To advance the performance cast iron and steel are alloyed $(\mathrm{Cr}, \mathrm{Ni}, \mathrm{Mo}, \mathrm{Nb}$ and other chemical elements); not only grey cast iron but also malleable cast iron and high-strength cast iron with globular graphite are employed [8, 9].

Grey cast iron is a cheap fragile material. Malleable cast iron is more ductile and stronger than grey cast iron. It is also cold-resistant, durable, withstands dynamic and vibration loads. Cast iron with globular graphite has high level of ultimate tensile strength, compression and bending strength. Cast iron flanged valves are not employed in systems with high pressure and systems where abrupt pressure jumps occur in liquid medium (water hammer).

One of the efficient methods for increasing chemical resistance of flanged valves in high pressure systems is employment of combined castings. Their internal part is made of ceramics and external part is made of cheap alloys (brass, bronze, cast iron, steel).

The most promising solution of this task is the use of combined castings, in particular metal and ceramics compound. Compared to ceramic-metal products (cermet), corrosive medium does not affect the metal part of combined castings that significantly improves their resistance qualities, reliability and lifetime performance while eliminating the use of high alloys.

Cast combined parts have been applied neither in manufacturing processes nor in housekeeping so far. It has been particularly caused by data gap of feasibility of such products, for instance, lack of data regarding their reliability, operability, durability, and stress indices observed in the walls of combined castings while they are pressurized.

The ways of production and operation processes can influence the range of characteristics typical for combined castings.

In case a combined casting is employed under low pressure of a working body, for example, at $p_{V} \leq 0.5 \mathrm{MPa}$, the main and sufficient factor of such casting successful operation is the integrity preservation of its metal part during hardening and cooling in a casting mould. If a combined casting is employed under high pressure of a working body $\left(p_{V}>0.5 \mathrm{MPa}\right)$ which, in particular, is corrosive medium, then the additional requirements to such casting will be not only an integrity preservation at its formation in a casting mould, but also integrity of both a ceramic insert and the casting.

Taking into account that ceramic materials possess high compression strength as well as fragility and con- siderably lower tensile strength, in order to keep the materials integrity it is necessary to provide such operating conditions of the combined casting where tensile stress in a ceramic insert would not exceed the total value of tensile strength and compression stress. At the same time the sum of the tensile stress and residual tensile stress in a casting material should not exceed the casting material ultimate strength.

Objectives of the article. The purpose is to develop a mathematical model for making theoretical analysis regarding the effect of design factors of the combined hollow cylindrical casting on a maximum pressure limit of a working body in it.

Methods. Data represented in classical theoretical research studies by various scientists specialized in material and structural performance evaluation have been applied.

Results. In order to solve the outlined task the workpiece (combined casting) which is schematically presented in Fig. 1 is to be analyzed.

According to Fig. 1 the workpiece is produced as a hollow two-component cylinder with an internal part in the form of ceramic insert, and an external part in the form of the casting. At the same time since the ceramic insert was the casting's core during the formation, there is a certain preliminary tension (D) in the considered workpiece (system) between casting and a ceramic insert. This causes the situation when in an initial state (in the circular direction) casting material is in the stretched state while the ceramic insert material is compressed.

If the internal pressure $p_{V}$ is applied to such combined casting, it will cause additional stress in it. The combined casting represents a two-layer cylinder with different physical parameters of layers. Therefore, with internal pressure $p_{V}$ the additional unknown contact pressure $p_{C V}$ arises between layers, which is necessary for the determination of additional stresses in each layer. In order to determine $p_{C V}$ the insert and the casting should be imaginary separated while their interaction on each other should be replaced with the unknown contact pressure $p_{C V}$. To determine this pressure the condition of equality of resetting (moving) casting internal radius points $u_{1}\left(r_{C}\right)$ and ceramic insert external radius $u_{2}\left(r_{C}\right)$ is to be followed

$$
u_{1}\left(r_{C}\right)=u_{2}\left(r_{C}\right)
$$

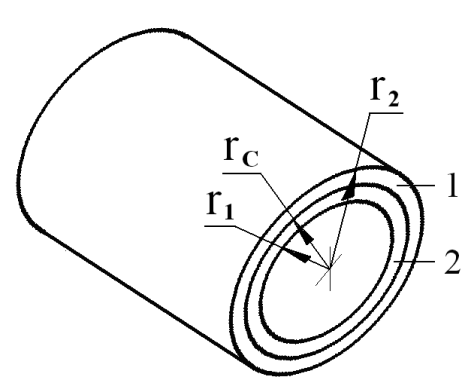

Fig. 1. The design of cylindrical combined casting:

1 - casting; 2 - ceramic insert; $r_{1}$ - the ceramic insert internal radius; $r_{2}$ - the casting external radius; $r_{C}-$ the radius of cylinders conjugacy 
Additional stresses and additional movements can be calculated by Lame formulas $[10,11]$ in the compound cylinder:

- for the ceramic insert $r_{1} \leq r \leq r_{C}$

$$
\begin{array}{r}
\sigma_{r p}=-\frac{r_{1}^{2}}{r_{c}^{2}-r_{1}^{2}}\left(\frac{r_{c}^{2}}{r^{2}}-1\right) \cdot p_{v}-\frac{r_{c}^{2}}{r_{c}^{2}-r_{1}^{2}}\left(1-\frac{r_{1}^{2}}{r^{2}}\right) \cdot p_{c v} \\
\sigma_{t p}=\frac{r_{1}^{2}}{r_{c}^{2}-r_{1}^{1}}\left(\frac{r_{c}^{2}}{r^{2}}+1\right) \cdot p_{v}-\frac{r_{c}^{2}}{r_{c}^{2}-r_{1}^{2}}\left(1+\frac{r_{1}^{2}}{r^{2}}\right) \cdot p_{c v} \\
u_{2}(r)=\frac{1-\mu_{2}}{E_{2}} \frac{r_{1}^{2} p_{v}-r_{c}^{2} p_{c v}}{r_{c}^{2}-r_{1}^{2}} \cdot r+\frac{1+\mu_{2}}{E_{2}} \frac{r_{1}^{2} r_{c}^{2}\left(p_{v}-p_{c v}\right)}{r_{c}^{2}-r_{1}^{2}} \cdot \frac{1}{r}
\end{array}
$$

- for the casting $r_{C} \leq r \leq r_{2}$

$$
\begin{gathered}
\sigma_{r o p}=-\frac{r_{c}^{2}}{r_{2}^{2}-r_{c}^{2}}\left(\frac{r_{2}^{2}}{r^{2}}-1\right) \cdot p_{c v} ; \\
\sigma_{t o p}=\frac{r_{c}^{2}}{r_{2}^{2}-r_{c}^{2}}\left(\frac{r_{2}^{2}}{r^{2}}+1\right) \cdot p_{c v} \\
u_{1}(r)=\left(\frac{1-\mu_{1}}{E_{1}} \frac{r_{c}^{2}}{r_{2}^{2}-r_{c}^{2}} \cdot r+\frac{1+\mu_{1}}{E_{1}} \frac{r_{c}^{2} r_{2}^{2}}{r_{2}^{2}-r_{c}^{2}} \cdot \frac{1}{r}\right) \cdot p_{c v}
\end{gathered}
$$

where $\sigma_{r p}$ is additional radial stress from pressure $p_{V} ; \sigma_{t p}$ is additional tangential stress from pressure $p_{V} ; r_{1}$ is the ceramic insert internal radius; $r_{2}$ is the casting external radius; $r_{C}$ is the radius of cylinders conjugacy; $E_{1}, E_{2}$ are Jung's modules of ceramic insert material and the casting respectively; $\mu_{2}, \mu_{1}$ are Poisson's ratios of ceramic insert material and the casting respectively (Fig. 1).

Assuming that $r=r_{c}$ in (4) and (6) and substituting them in (1), the following equation is deduced

$$
\begin{gathered}
\frac{1}{E_{2}} \cdot \frac{2 r_{1}^{2}}{\left(r_{c}^{2}-r_{1}^{2}\right)} \cdot p_{v}= \\
=\left(\frac{1}{E_{2}}\left(\frac{r_{c}^{2}+r_{1}^{2}}{r_{c}^{2}-r_{1}^{2}}-\mu_{2}\right)+\frac{1}{E_{1}}\left(\frac{r_{2}^{2}+r_{c}^{2}}{r_{2}^{2}-r_{c}^{2}}+\mu_{1}\right)\right) \cdot p_{c v},
\end{gathered}
$$

where the contact pressure $p_{c v}$ can be calculated of internal pressure

$$
p_{c v}=K_{v} \cdot p_{v}
$$

where

$$
K_{v}=\frac{\frac{2 r_{1}^{2}}{r_{c}^{2}-r_{1}^{2}}}{\frac{E_{2}}{E_{1}}\left(\frac{r_{2}^{2}+r_{c}^{2}}{r_{2}^{2}-r_{c}^{2}}+\mu_{1}\right)+\left(\frac{r_{c}^{2}+r_{1}^{2}}{r_{c}^{2}-r_{1}^{2}}-\mu_{2}\right)}
$$

As stated above, before applying internal pressure $p_{V}$ to the combined casting there is already tensile stress (D) in a ceramic insert $\left(r_{1} \leq r \leq r_{C}\right)$ :

- radial stress

$$
\sigma_{r \Delta}=-\frac{r_{c}^{2}}{r_{c}^{2}-r_{1}^{2}}\left(1-\frac{r_{1}^{2}}{r^{2}}\right) \cdot p_{c \Delta}
$$

- tangential stress

$$
\sigma_{t \Delta}=-\frac{r_{c}^{2}}{r_{c}^{2}-r_{1}^{2}}\left(1+\frac{r_{1}^{2}}{r^{2}}\right) \cdot p_{c \Delta},
$$

and radial stress in casting $\left(r_{C} \leq r \leq r_{2}\right)$

$$
\sigma_{r o \Delta}=-\frac{r_{c}^{2}}{r_{2}^{2}-r_{c}^{2}}\left(\frac{r_{2}^{2}}{r^{2}}-1\right) \cdot p_{c \Delta}
$$

- tangential stress

$$
\sigma_{t o \Delta}=\frac{r_{c}^{2}}{r_{2}^{2}-r_{c}^{2}}\left(\frac{r_{2}^{2}}{r^{2}}+1\right) \cdot p_{c \Delta}
$$

where $p_{C D}$ represents the pressure on the contact surface between an insert and casting caused by $\mathrm{D}$ tension

$$
\begin{gathered}
p_{c \Delta}=K_{\Delta} \cdot \Delta \\
\frac{r_{c}}{E_{1}}\left(\frac{r_{2}^{2}+r_{c}^{2}}{r_{2}^{2}-r_{c}^{2}}+\mu_{1}\right)+\frac{r_{c}}{E_{2}}\left(\frac{r_{c}^{2}+r_{1}^{2}}{r_{c}^{2}-r_{1}^{2}}-\mu_{2}\right)
\end{gathered}
$$

Resultant contact pressure between an insert and casting is deduced by summing up formulations (8) and (14)

$$
p_{c}=K_{v} \cdot p_{v}+K_{\Delta} \cdot \Delta \text {. }
$$

Proceeding from this condition (1) when internal pressure $p_{V}$ is applied, stresses $(2,3,5,6)$ from $p_{V}$ are algebraically summarized with already present tensile stress D (10-13). Therefore, taking (16) into account, we receive $r_{1} \leq r \leq r_{C}$ in a ceramic insert:

- radial stress

$$
\sigma_{r b}=-\frac{r_{1}^{2}}{r_{c}^{2}-r_{1}^{2}}\left(\frac{r_{c}^{2}}{r^{2}}-1\right) \cdot p_{v}-\frac{r_{c}^{2}}{r_{c}^{2}-r_{1}^{2}}\left(1-\frac{r_{1}^{2}}{r^{2}}\right) \cdot p_{c}
$$

- tangential stress

$$
\sigma_{r b}=\frac{r_{1}^{2}}{r_{c}^{2}-r_{1}^{2}}\left(\frac{r_{c}^{2}}{r^{2}}+1\right) \cdot p_{v}-\frac{r_{c}^{2}}{r_{c}^{2}-r_{1}^{2}}\left(1+\frac{r_{1}^{2}}{r^{2}}\right) \cdot p_{c}
$$

and in the casting $r_{C} \leq r \leq r_{2}$ :

- radial stress

$$
\sigma_{r o p}=-\frac{r_{c}^{2}}{r_{2}^{2}-r_{c}^{2}}\left(\frac{r_{2}^{2}}{r^{2}}-1\right) \cdot p_{c}
$$

- tangential stress

$$
\sigma_{t o p}=\frac{r_{c}^{2}}{r_{2}^{2}-r_{c}^{2}}\left(\frac{r_{2}^{2}}{r^{2}}+1\right) \cdot p_{c} .
$$

In a ceramic insert in terms of the absence of internal pressure $\left(p_{V}=0\right)$ and existence of tension $\Delta$, the radial and tangential stresses are compressive at any parameters as it follows from formulas (15-18).

If the tension equals zero and only internal pressure is applied, then stresses are in direct proportion to pressure $p_{V}$. Radial stresses will also be negative at all parameters (17), and the sign of tangential stresses, generally speaking, is not defined. However, referring to the data represented in Table and monotony of functions of stresses at the considered physical and geometrical pa- 
rameters, tangential stresses calculated with a formula (18), taking into account $(8,9,16)$ are positive. That is why when the tension occurs and internal pressure is applied total tangential stress decreases, so the core is unloaded.

The level of internal stresses in the insert and the casting with other equal conditions depends, at the same time, on a large-scale factor which is confirmed with the data analysis presented in Table 1, where one can see the tangential stress values in a ceramic insert $\sigma_{\mathrm{t} B}\left(r_{1}\right), \sigma_{t B}\left(r_{C}\right)$ $\left(E_{2}=36\right.$ MPas, $\left.\mu_{2}=0.25\right)$ while there is no tension $(D=0)$, in terms of the internal pressure $p_{V}=50 \mathrm{MPas}$ and the casting made of constructional steel with $0.3 \%$ carbon content $\left(E_{1}=100 \mathrm{MPas}, \mu_{1}=0.25\right)$. Dependencies $\sigma_{t B}\left(r_{C}\right)=f\left(r_{1}, r_{2}, r_{C}\right)$ deduced from the data in Table are presented in Fig. 2.

Operating stresses and tensile stresses have identical signs in the casting (radial stresses are compressive (18), tangential stresses are stretching (19)). As a result, the stresses are increased in terms of presence of preliminary tension in the casting. These values will be the highest in a contact area of cylinders. This requires the check of durability in this part of the considered system.

In order to determine the maximum pressure limit for $p_{V}$ two conditions can be outlined.

Condition I. Stresses in the insert should not be stretching.

Radial stresses, as it has been stated above, according to (17) are compressive at any parameters. Expression of tangential stresses (18) for the considered area of physical parameters is the monotonous function. Hence, condition I is equivalent to the system of two conditions

$$
\left\{\begin{array}{l}
\sigma_{t b}\left(r_{1}\right) \leq 0 \\
\sigma_{t b}\left(r_{c}\right) \leq 0
\end{array}\right.
$$

Inserting mathematical expression (18) in (21) we come to

$$
\left\{\begin{array}{l}
\left(\left(r_{c}^{2}+r_{1}^{2}\right)-2 r_{c}^{2} \cdot K_{V}\right) \cdot p_{v}-2 r_{c}^{2} K_{\Delta} \cdot \Delta \leq 0 \\
\left(2 r_{1}^{2}-\left(r_{c}^{2}+r_{1}^{2}\right) \cdot K_{v}\right) \cdot p_{v}-\left(r_{c}^{2}+r_{1}^{2}\right) \cdot K_{\Delta} \cdot \Delta \leq 0
\end{array} .\right.
$$

If coefficients at $p_{V}$ in both inequalities (22) are negative, then these inequalities are complied with any geometrical and physical parameters.

If both of these coefficients are positive, then we come to inequalities system with regard to $p_{V}$
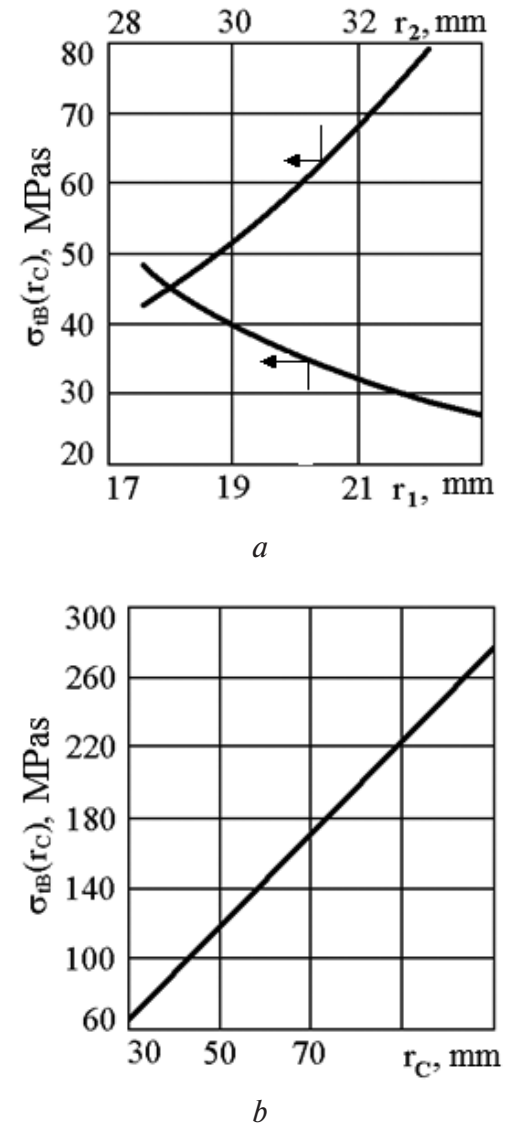

Fig. 2. Dependencies $\sigma_{t B}\left(r_{C}\right)=f\left(r_{1}, r_{2}\right)(a)$ and $\sigma_{t B}\left(r_{C}\right)=$ $=f\left(r_{C}\right)(b)$ :

$r_{1}$ - the ceramic insert internal radius; $r_{2}$ - the casting external radius; $r_{C}$ - the radius of cylinders conjugacy

$$
\left\{\begin{array}{l}
p_{v} \leq \frac{2 r_{c}^{2} K_{\Delta} \cdot \Delta}{\left(r_{c}^{2}+r_{1}^{2}\right)-2 r_{c}^{2} \cdot K_{v}} \\
p_{v} \leq \frac{\left(r_{c}^{2}+r_{1}^{2}\right) K_{\Delta} \cdot \Delta}{2 r_{1}^{2}-\left(r_{c}^{2}+r_{1}^{2}\right) \cdot K_{v}}
\end{array} .\right.
$$

If the coefficient at $p_{V}$ in the first inequality (22) is positive, whereas in the second inequality (22) it is negative then only the first condition remains out of the system (23).

Vice versa only the second condition remains out of the system (23), if the coefficient at $\mathrm{pV}$ in the first inequality (22) is negative, and in the second inequality (22) it is positive (24).

\begin{tabular}{|c|c|c|c|c|c|c|c|c|c|c|c|}
\hline$=$ & $r_{1}$ & $r_{C}$ & $r_{2}$ & $\sigma_{t B}\left(r_{1}\right)$ & $\sigma_{t B}\left(r_{C}\right)$ & \multirow{2}{*}{$\frac{F}{\infty}$} & $r_{1}$ & $r_{\mathrm{C}}$ & $r_{2}$ & $\sigma_{t B}\left(r_{1}\right)$ & $\sigma_{t B}\left(r_{C}\right)$ \\
\hline 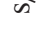 & \multicolumn{3}{|c|}{$\mathrm{mm}$} & \multicolumn{2}{|c|}{ MPas } & & \multicolumn{3}{|c|}{$\mathrm{mm}$} & \multicolumn{2}{|c|}{ MPas } \\
\hline 1 & 18 & 25 & 29 & 75.41 & 45.21 & 5 & 18 & 25 & 34 & 51.216 & 26.843 \\
\hline 2 & 20 & 25 & 29 & 83.36 & 59.36 & 6 & 25 & 30 & 35 & 85.06 & 64.42 \\
\hline 3 & 22 & 25 & 29 & 93.41 & 77.23 & 7 & 50 & 55 & 60 & 148.04 & 130.86 \\
\hline 4 & 18 & 25 & 31 & 62.37 & 35.31 & 8 & 100 & 105 & 110 & 278.63 & 263.35 \\
\hline
\end{tabular}

Table

The values of tangential stress in a ceramic insert and steel casting 
Condition II. The maximum shear stress theory is to be followed in the external cylinder (casting) on its inner side

$$
\sigma_{e q u}^{\mathrm{III}}=\sigma_{1}-\sigma_{3} \leq[\sigma],
$$

where $\sigma_{e q u}^{\mathrm{III}}$ is equivalent stress according to the mentioned above theory; $\sigma_{1}$ is the highest main stress; $\sigma_{3}$ is the lowest main tension; $[\sigma]$ is the allowable stress for casting material.

In this case (case of flat deformation)

$$
\sigma_{1}=\sigma_{t o}\left(r_{c}\right) ; \quad \sigma_{3}=\sigma_{r o}\left(r_{c}\right) .
$$

Inserting (24) in (23) taking into account $(19,20)$ we come to

$$
\sigma_{e q u}^{\text {III }}=\frac{2 r_{2}^{2}}{r_{2}^{2}-r_{c}^{2}}\left(K_{v} p_{v}+K_{\Delta} \Delta\right) \leq[\sigma] .
$$

That results in one more condition on $\mathrm{pV}$

$$
p_{v} \leq \frac{\left(r_{2}^{2}-r_{c}^{2}\right)}{2 r_{2}^{2}} \frac{[\sigma]}{K_{v}}-\frac{K_{\Delta} \Delta}{K_{v}} .
$$

The lowest value from the highest values of internal pressure $p_{V}$ that complies with inequalities $(23,26)$ is to be chosen. This lowest pressure value is the allowable internal pressure $\left[p_{V}\right]$. Contact pressure between the insert and the casting, including stresses in them, are calculated according to the formulas $(16-20)$ where it is necessary to apply $p_{V}=\left[p_{V}\right]$.

Thus, the following algorithm for defining authorized internal pressure $\left[p_{V}\right]$ can be presented.

1. The values $K_{v}$ and $K_{D}$ are calculated by formula (9) and (15), relatively.

2. The highest value of $p_{v 1}$ contact pressure $p_{v}$ that satisfies inequality (27) is calculated

$$
p_{v_{1}}=\frac{\left(r_{2}^{2}-r_{c}^{2}\right)}{2 r_{2}^{2}} \frac{[\sigma]}{K_{v}}-\frac{K_{\Delta} \Delta}{K_{v}}
$$

3. The system of inequalities (22) calculates the value of coefficients at contact pressure $\mathrm{pV}$.

$$
\begin{aligned}
& K_{2}=\left(r_{c}^{2}+r_{1}^{2}\right)-2 r_{c}^{2} \cdot K_{v} ; \\
& K_{3}=2 r_{1}^{2}-\left(r_{c}^{2}+r_{1}^{2}\right) \cdot K_{v} .
\end{aligned}
$$

4. If both coefficients $K_{2}, \mathrm{~K}_{3}$ are positive, then the highest values $p_{v 2}, p_{v 3}$ of contact pressure $p_{V}$, that satisfy the system of inequalities (23) are calculated

$$
\begin{aligned}
& p_{v_{2}}=\frac{2 r_{c}^{2} K_{\Delta} \cdot \Delta}{\left(r_{c}^{2}+r_{1}^{2}\right)-2 r_{c}^{2} \cdot K_{v}} ; \\
& p_{v_{3}}=\frac{\left(r_{c}^{2}+r_{1}^{2}\right) \cdot K_{\Delta} \cdot \Delta}{2 r_{1}^{2}-\left(r_{c}^{2}+r_{1}^{2}\right) \cdot K_{v}}
\end{aligned}
$$

and authorized internal pressure $\left[p_{V}\right]$ is defined as the lowest values o $p_{v 1}, p_{v 2}, p_{v 3}$

$$
\left[p_{v}\right]=\min \left\{p_{v 1}, p_{v 2}, p_{v 3}\right\} .
$$

5. If coefficient $K_{2}$ is positive, and $K_{3}$ is negative, then only $p_{v 2}$ is calculated according to (28) and authorized internal pressure $\left[p_{V}\right]$ is defined as the lowest values, $p_{v 1}, p_{v 2}$

$$
\left[p_{v}\right]=\min \left\{p_{v 1}, p_{v 2}\right\} .
$$

6. If coefficient $K_{2}$ is negative, and $K_{3}$ is positive, then only, $p_{v 3}$ is calculated according to (29) and authorized internal pressure is defined as the lowest values $p_{v 1}, p_{v 3}$

$$
\left[p_{v}\right]=\min \left\{p_{v 1}, p_{v 3}\right\} .
$$

Proceeding from the fact that metal component of a combined casting have to withstand the pressure of the working medium (gas, fluid) that significantly exceeds its working value without destruction and loss of working capacity under field conditions in an emergency, the required minimal permissible elastic limit of metal component (material) of a combined casting is calculated by formula

$$
\sigma_{0.05}=k \cdot\left[\sigma_{t B}\left(r_{2}-r_{C}\right)-1+p_{V}\right],
$$

where $k$ is a coefficient of reliability of the metal component of a combined casting.

As a rule, value $k$ is considered to equal the range from 1.1 to 5 (depending on the working conditions of flanged valves). In this case the material (alloy) for producing a combined casting is chosen in compliance with its lowest real value $\sigma_{0.05}$ in the range of working temperatures of the given flanged valves.

Conclusions. The mathematical model for making theoretical analysis regarding the effect of design factors of the combined hollow cylindrical casting on a maximum pressure limit of a working body in it has been developed. The application of this model facilitates calculations of the properties of the components included in a combined casting according to the dimensions of its components.

The results of theoretical analysis show that in twocomponent metal and ceramic compounds stresses grow with the increase in the metal component wall thickness and decrease in ceramic component wall thickness which contact with each other. The increase in contact radius of metal and ceramic components of a casting results in the increase in stresses in metal component by linear dependence in the range of radius variation from 30 to $100 \mathrm{~mm}$.

Nonlinearity of a range of obtained theoretical dependencies and the existence of limiting value of elastic stresses in metal component require the use of stress simulation of any cermet (a combination product), by numerical methods.

\section{References.}

1. Boyko, N., 2002. Pipeline "little things". Stroitelstvo $i$ rekonstruktsiya, 11, pp. 22-23. Available at: <http:// proxima.com.ua/articles/articles.php? clause $=3374>$ [Accessed 4 May 2017].

2. Afanaseva, O. V. and Bakulina, A. A., 2013. Russian valve industry in 2012. Analytical review. Vestnik Armaturschika, 10(3), pp. 24-32.

3. Myakinin, S. L. and Lyistsev, A. F., 2017. Ball valves of a new generation. Vestnik armaturostroitelya, 4(39), pp. $30-32$. 
4. Artemov, A. V., 2012. Development and production of stop valve stations from technical ceramics. Materialyi $v$ mashinostroenii [pdf], 6(81), pp. 66-68. Available at: $<$ http://www.monrf.ru/upload/iblock/8f1/8f16fdbc7db 45fba71fd01ce3832bc41.pdf $>$ [Accessed 15 June 2017].

5. Krasavin, A. S., 2018. Innovative methods of weld deposition for pipeline fittings. Vestnik armaturostroitelya, 2(44), pp. 90-96.

6. Vlasova, E., Kovalenko, V., Kotok, V. and Vlasov, S., 2016. Research of the mechanism of formation and properties of tripolyphosphate coating on the steel basis. Eastern-European Journal of Enterprise Technologies, 5(5(83)), pp. 33-39. DOI:10.15587/1729-4061.2016. 79559.

7. Shatrov, A.S. and Kokarev, V. N., 2014. New technology of industrial production of wear-resistant part of pipeline fittings from aluminum alloy with protective ceramic nanostructural coating. Vestnik armaturschika, 6(19), pp. 48-50.

8. Kakuzin, V.B., 2015. Characteristics of materials used for producing components of energetic fittings and the experience of operating them. Vestnik armaturschika, 3(23), pp. 94-98.

9. Boguslaev, V.A., Repyah, S. I. and Mogilatenko, V.G., 2016. Casting properties of metals and alloys for precision casting. Zaporozhe: AO "Motor Sich".

10. Saragosa Silvano, 2010. Mathematical model of the Lamé Problem for Simplified Elastic Theory applied to Controlled-Clearance Pressure Balances. In: The Simplified Elastic Theory applied to controlled-clearance pressure balances. Available at: <https://arxiv.org/abs/ 1007.0813> [Accessed 28 April 2017].

11. Zaytsev, V. Yu. and Porunov, D. S., 2014. Models of strain-stress state of thick wall cylinders. Nauchno-metodicheskiy elektronnyi zhurnal "Kontsept” 20, pp. 1771-1775. Available at: <http://e-koncept.ru/2014/54618.htm> [Accessed 1 May 2017].

\section{Напруження в порожніх циліндричних комбінованих виливках}

\section{В. Ф. Мазорчук, I. Ю. Наумова, С. І. Реп'ях, С. Ф. Шаркова}

Національна металургійна академія України, м. Дніпро, Україна, e-mail: MazorchukVF@gmail.com; irnaumova. nmetau@gmail.com; 123rs@ua.fm

Мета. Розробка математичної моделі для проведення теоретичної оцінки впливу конструктивних факторів і фізичних властивостей матеріалів комбінованої порожньої циліндричного виливку на гранично допустиму величину тиску робочого тіла (газу, рідини) у ній.

Методика. Застосовані методи порівняльного аналізу, математичного моделювання та прогнозування.

Результати. Представлена математична модель для проведення теоретичної оцінки впливу конструктивних чинників комбінованої порожнистої циліндричної виливки на гранично допустиму величину тиску робочого тіла в ній.

Наукова новизна. За результатами проведення теоретичних досліджень показана можливість ви- готовлення комбінованих литих виробів, що працюють за підвищених внутрішніх тисках робочого середовища. Розроблена математична модель дозволяє оцінити вплив властивостей використовуваних матеріалів і розмірних факторів виливки на граничні умови її експлуатації.

Практична значимість. Використання даної моделі дозволяє здійснювати розрахунок властивостей елементів циліндричної форми порожнього комбінованого виливка 3 урахуванням їх геометричних розмірів. Отримані дані можна використовувати при проектуванні комбінованих литих виробів, наприклад, запірної арматури.

Ключові слова: комбінований виливок, керамічна вставка, радіальні й тангенціальні напруження

\section{Напряжения в полых цилиндрических комбинированных отливках}

\author{
В. Ф. Мазорчук, И. Ю. Наумова, С. И. Репях, \\ С. Ф. Шаркова
}

Национальная металлургическая академия Украины, г. Днепр, Украина, e-mail: MazorchukVF@gmail.com; irnaumova.nmetau@gmail.com; 123rs@ua.fm

Цель. Разработка математической модели для проведения теоретической оценки влияния конструктивных факторов и физических свойств материалов комбинированной полой цилиндрической отливки на предельно допустимую величину давления рабочего тела (газа, жидкости) в ней.

Методика. Применены методы сравнительного анализа, математического моделирования и прогнозирования.

Результаты. Представлена математическая модель для проведения теоретической оценки влияния конструктивных факторов комбинированной полой цилиндрической отливки на предельно допустимую величину давления рабочего тела в ней.

Научная новизна. По результатам проведения теоретических исследований показана возможность изготовления комбинированных литых изделий, работающих при повышенных внутренних давлениях рабочей среды. Разработанная математическая модель позволяет оценить влияние свойств используемых материалов и размерных факторов отливки на граничные условия ее эксплуатации.

Практическая значимость. Использование данной модели позволяет осуществлять расчёт свойств элементов цилиндрической формы полой комбинированной отливки с учётом их геометрических размеров. Полученные данные можно использовать при проектировании комбинированных литых изделий, например, запорной арматуры.

Ключевые слова: комбинированная отливка, керамическая вставка, радиальные и тангенциальные напряжения

Рекомендовано до публікації докт. техн. наук В. Т. Калініним. Дата надходження рукопису 08.05.17. 